\title{
Natural and Anthropogenic Disturbance Influences on Aquatic Biological Diversity in the Pacific Northwest
}

\author{
Robert J. Danehy, ${ }^{1, *}$, Andrew R. Moldenke ${ }^{2}$ \\ ${ }^{1}$ National Council for Air and Stream Improvement, Inc., United States \\ ${ }^{2}$ Department of Botany and Plant Pathology, Oregon State University, United States
}

Copyright $(2016$ by authors, all rights reserved. Authors agree that this article remains permanently open access under the terms of the Creative Commons Attribution License 4.0 International License

\begin{abstract}
Aquatic biological diversity in Pacific Northwest (PNW) forests was examined after two disturbance types: natural (flooding with and without associated debris flows); and anthropogenic (canopy removal). Within the region two multi-decade studies on aquatic insects in western Oregon establish the likely upper ends of forested stream richness, with richness values of $\approx 300$ taxa collected at Berry Creek and 449 taxa within a small watershed (Lookout Creek, 6400 ha). Therefore, compared to intensively studied sites, at least 100 to 200 species have not been documented at these sites. We examine disturbance impacts on assemblage richness in the PNW with data from three studies characterized by similar levels of sampling and taxonomic effort. Rare species were important contributors to richness, as 20 to $30 \%$ of taxa within each study area were found at only one site. Mature, clearcut, high flow, and debris flow disturbance states were compared. Ephemeroptera $(\mathrm{p}=<0.001)$ richness increased after debris flows and high flows, and Chironomidae $(\mathrm{p}=0.04)$ increased after debris flows and clearcutting. Site variability was high, with assemblage structure weakly clustered by disturbance severity as debris flow disturbance (characterized by both streambed and canopy removal) mostly separated from high flow and clearcut disturbances.
\end{abstract}

Keywords Debris Flow, Disturbance, Flood, Forest, Harvest, Macroinvertebrates, Stream

\section{Introduction}

Maintaining biological diversity in managed landscapes is a stewardship challenge for forest managers. As a general rule, stewardship usually focuses on specific species (driven by endangered species regulations) that are not a measure of biological diversity. Examination of whole communities of more speciose-stream benthic invertebrate species will provide a qualitatively different and better test to understand stream networks in managed landscapes. These landscapes experience infrequent very large storm events and systematic canopy removal disturbances. Within a landscape, stream length consists mostly of small streams. These headwater and low-order streams provide habitat that supports a large number of species, many of which are not found anywhere else in the river system, and thus enhance biological diversity of the entire watershed [1,2]. Long-term studies of the invertebrate fauna in a single first-order German stream have identified over 1,000 taxa, many of which are micro-fauna living in the hyporheic zone with connections to ground water [3]. Meyer et al.[1] estimated the macroinvertebrate diversity for three fishless first-order streams in the southern Appalachian Mountains to be just under 300 taxa. Because the non-insect taxa are less intensively studied and therefore have less robust taxonomic clarity, the authors suggested that the true richness of the streams may be twice their reported estimates.

Larger flora and fauna are well documented in temperate forested landscapes. However, not much is known about the occurrence or diversity of some groups of organisms [4], particularly smaller ones such as bryophytes and certain invertebrates. This is due in part to the fact that many species occupy less-sampled habitats (e.g., headwaters, hyporheic zones) and many ecological studies do not examine taxa at the species level. In some instances, such as with Diptera, taxa are often not identified past family level [1]. Despite the lack of specific knowledge for some taxa, riparian systems (stream and forested buffer) are legally designated as being important to maintaining biological diversity in managed forests [5]. Biological diversity of riparian systems in managed forests is poorly understood, but because aquatic systems support a largely unique suite of flora and fauna their contribution to overall diversity is crucial [6].

Forested landscapes change through time with disturbances [7,8]. Reoccurrence intervals (RI) for various disturbances in the Pacific Northwest (PNW) vary by hundreds of years. Stand replacement fire RI is 300 to 500 years in moist westside PNW forests [8], debris flow RI is $\approx 150$ years in the Oregon Coast Range [9], and Douglas-fir harvest RI is $<100$ years. Forest harvest occurs most 
frequently, and in a spatial scale that includes the entire watershed in some cases. Modern forest practices have been implemented to minimize current impacts and will provide the most benefit when mandated riparian buffers mature [10]. In larger streams where riparian forests were removed at first harvest, it will require centuries for a new forest to provide both adequate shading and large-wood loading [11,12]. Shading becomes effective sooner as streams decline in size, so stream conditions can recover more quickly in lower order systems.

We assess disturbance types with a biological measure taxa richness. We hypothesize that four disturbance treatments will evidence increasing severity in the following order: (1) mature (M) sites were forests more than 50 years of age and neither physical habitat nor thermal conditions were changed; (2) clearcuts (CC) had the entire canopy removed (no remaining shady corridor, but stream bed was not disturbed), changes in thermal conditions have been reported in similar conditions [13,14]; (3) high flow (HF) sites had bed material extensively rearranged and flooded banks, while riparian vegetation remained largely intact [15]; and (4) debris flow (DF) sites had bed, banks, and much of the canopy removed with a subsequent partial deposition of new bed material, but with about $25 \%$ bare bedrock as well, extensive changes in both physical habitat and thermal conditions occurred [15]. All of the disturbed treatments had intact forest remnants situated upstream from the disturbance, which we assumed would provide sources for subsequent colonists. We hypothesized that canopy removal (treatments 2 and 4) would increase both autochthonous energy sources and temperature, and lead to higher densities and richness relative to the maturing forest. Whereas high flow would decrease richness due to deleterious disturbance of the streambed (no change in insolation), the debris flow increase due to insolation would be partially counterbalanced by the extremely negative effect of stream and bank removal.

To examine disturbance type and macroinvertebrate response in the PNW, we set a macroinvertebrate benchmark of the approximate upper richness one could expect from wadeable streams. We then contrasted macroinvertebrate responses to two types of disturbances using three existing datasets: large storm events that (1) created high water flows and (2) induced debris flows in southwestern Washington State and the upper Calapooia River, and (3) small stream responses to timber harvest in the Oregon Coast Range. We investigated the assemblage responses at both family and species levels.

\section{Methods}

Two intensive studies provided an estimate of the likely upper limit of local richness in western Oregon. The first used a variety of methods, including extensive emergence trapping over a period of 25 years [16]. That site, Berry Creek, was located in the foothills on the eastern slope of the Oregon Coast Range. At HJ Andrews Experimental Forest, the 6400 ha Lookout Creek watershed in the Cascade Mountains, researchers used various collection methods for a decade in three small streams to develop a species list [17].

We compared aquatic insect assemblage composition and richness in three previous studies (Figure 1) that used similar methods and taxonomic efforts to create four disturbance types from three datasets. The three studies were: (1) an Oregon Coast Range study focused on impacts of timber harvest (18 sites) [18]; (2) a debris flow study in third-order streams of the Calapooia River (4 sites) where all sites were disturbed by either high flow or debris flow [15]; and (3) a debris flow study in the Chehalis watershed (11 sites) in southwestern Washington following a large storm. From those studies we selected four sites for each disturbance category: mature ( $\mathrm{M} ;>50$ yrs since harvest); clearcut (CC; mean 2.5 yrs post harvest) from the Coast Range study; and high flow (HF) and debris flow (DF) sites from the Calapooia and Chehalis watersheds $(8$ yrs and 2 yrs post disturbance).

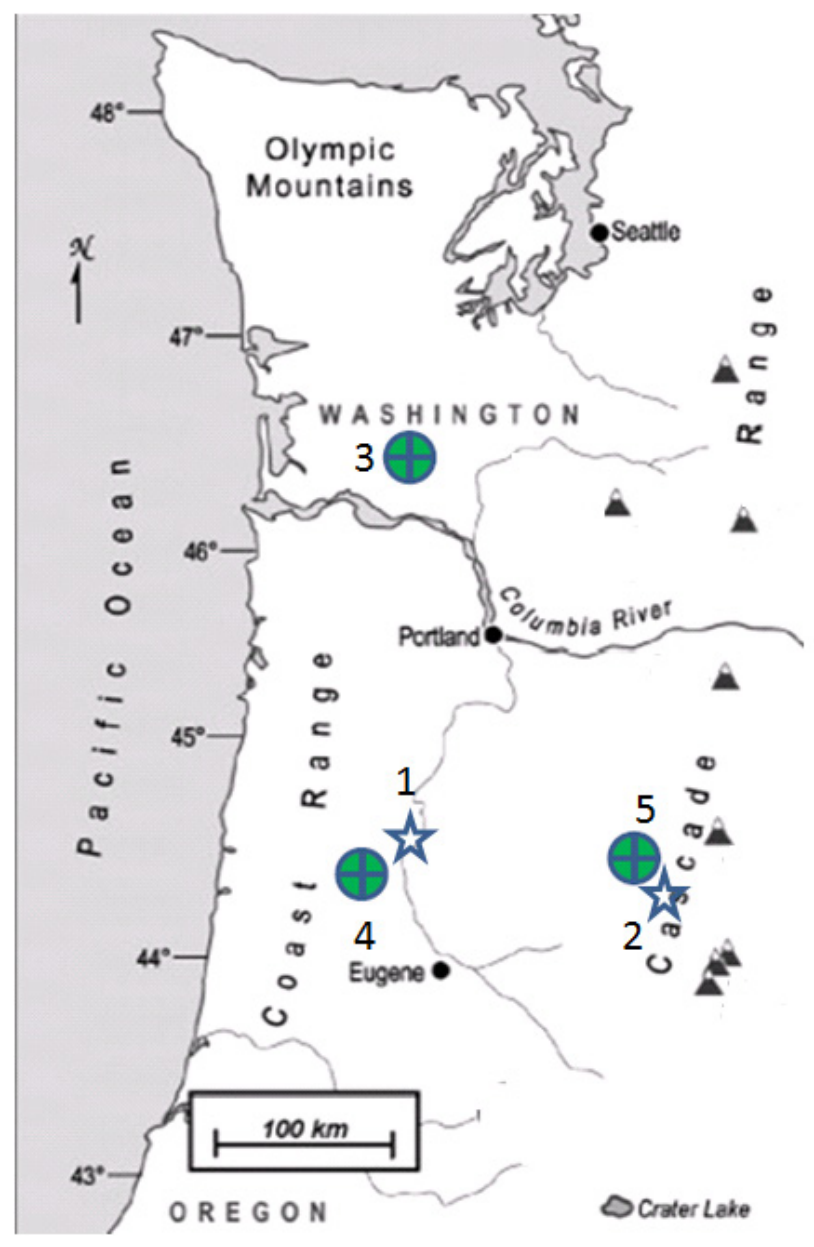

Figure 1. Relative location of two multi-year study locations [Berry Creek (1), HJ Andrews (2)] and three short-term study areas [Chehalis (3), Coast Range (4), and Calapooia (5)]

Richness in these studies with standard sampling effort was compared to the two multi-year intensive studies. In this study we focus only on aquatic insects whose taxonomy is better developed, which allows more complete estimation of 
species richness. In each study three surber ( $325 \mu \mathrm{m}$ mesh) samples were collected in three riffles in late spring or early summer. For this analysis the three separate pseudo-replicates were combined. Because taxa richness was our primary analysis metric, we attempted to identify all taxa to species (with some unavoidable exceptions for difficult taxa or early instars) with identifications of full samples or at least 1000 individuals from a sample. Given the range in density, we tested for a positive relationship between richness and abundance with Pearson's correlation coefficient, $r$. The family Chironomidae was targeted for special effort and many taxa were identified to species.

Differences in richness on the full assemblage and on the five major taxonomic categories Ephemeroptera, Plecoptera, Trichoptera, Chironomidae, and Other Taxa (includes the other Diptera and Coleoptera) among disturbances types were tested with Analysis of Variance $(\mathrm{p}<0.05)$ (One-way ANOVA, proc GLM, SAS 9.1). Recognizing the proven relationship of sample size and richness we acknowledge some probable influence on richness metrics; metrics based on percent of total were also used for comparisons. We evaluated the role of highly abundant taxa with two metrics: percent abundance of top three and top ten taxa. The two taxa groups that responded most strongly, various chironomid taxa and the genus Baetis spp., were calculated separately and differences were tested with Analysis of Variance $(p<0.05)$ (One-way ANOVA, proc GLM, SAS 9.1). Community organization of the five taxonomic categories at the 16 sites was analyzed with Hierarchical Agglomerative Cluster Analysis [19]. Richness values were square root-transformed and analyzed using Flexible beta $(-0.25)$ linkage and Sorensen distance methods. Analysis was performed both at full species separation resolution and at the five broader taxonomic categories.

\section{Results}

Two comprehensive studies on aquatic insects in western Oregon are available, with richness values of $\approx 300$ taxa [16] and 449 taxa [17] (Table1). We used these values as the probable upper ends of richness and focused on the role of disturbance in influencing richness in our three study areas, which each include at least two of the treatments. In the three projects measured, richness was 159, 165, and 192 taxa at Calapooia, Chehalis, and Coast Range, respectively, with individual site richness ranging from 52 to 90 taxa. Infrequent species were important contributors to richness in each project, as 20 to $30 \%$ of taxa within each site were found at only one of the locations. Total richness for all sites combined in those projects was about half that of the Berry Creek and HJ Andrews small watersheds.

The two well-studied areas have different contributions of the major aquatic insect orders (Table 1). The studies were conducted in different settings. Berry Creek is in the eastern Coast Range foothills with more deciduous vegetation, while Lookout Creek at the HJ Andrews is in the Cascade Mountains and was primarily under coniferous cover. The Cascade location had a higher percentage of Trichopterans, whereas Diptera and Coleoptera were richer at Berry Creek. With reference to the disturbance sites, relative contributions of taxonomic categories were similar except for two categories. The percentage of Ephemeroptera taxa was higher at flood-related disturbances, and fewer Trichoptera were found at disturbance locations compared to the more intensively sampled sites.

Total richness was partitioned in the disturbance studies into five taxonomic categories, revealing differences among disturbance types (Table 2). Two responses are apparent. Ephemeroptera responded strongly $(p<0.001)$ to flood related disturbances (HF and DF). Chironomidae richness ( $p$ $=0.04)$ was higher at $\mathrm{CC}$ and $\mathrm{DF}$ disturbance sites.

Table 1. Relative Contributions (percent of total) of Common Aquatic Insect Orders at Two Intensive Locations and Three Disturbance Study Areas (Notes: disturbance studies Diptera are listed with number of Chironomidae in parentheses; Hemipterans were not included in disturbance study taxonomy)

\begin{tabular}{|c|c|c|c|c|c|c|c|c|}
\hline & Coleoptera & Diptera & Ephemeroptera & Hemiptera & Megaloptera & Odonata & Plecoptera & Trichoptera \\
\hline \multicolumn{9}{|l|}{ Intensive Studies } \\
\hline Berry Creek & 11 & 48 & 8 & 3 & 1 & 1 & 12 & 17 \\
\hline HJ Andrews & 4 & 39 & 10 & 2 & $<1$ & 2 & 14 & 30 \\
\hline \multicolumn{9}{|l|}{ Disturbance Studies } \\
\hline Coast Range & 13 & $42(30)$ & 11 & NA & $<1$ & $<1$ & 20 & 13 \\
\hline SW Washington & 12 & $43(27)$ & 23 & NA & $<1$ & $<1$ & 13 & 9 \\
\hline
\end{tabular}

Table 2. Comparison of Richness Treatment Means of Five Major Taxonomic Categories across Disturbance Categories

\begin{tabular}{|c|c|c|c|c|c|}
\hline Treatment Means & Mature (M) & Clearcut (CC) & High Flow (HF) & Debris Flow (DF) & $\mathrm{p}$ \\
\hline All taxa & 53.5 & 70.8 & 69.4 & 88.8 & 0.002 \\
\hline Ephemeroptera & 6.0 & 8.5 & 14.5 & 18.3 & $<0.001$ \\
\hline Plecoptera & 11.7 & 12.0 & 11.3 & 12.5 & 0.95 \\
\hline Tricoptera & 8.0 & 8.5 & 10.3 & 10.0 & 0.71 \\
\hline Chironomidae & 16.5 & 27.3 & 18.0 & 29.5 & 0.04 \\
\hline Other & 11.3 & 14.5 & 15.3 & 18.5 & 0.17 \\
\hline
\end{tabular}


Table 3. Comparison of Treatment Abundance with Emphasis on Impact of Highly Abundant Taxa, Chironomids, and Baetids

\begin{tabular}{|c|c|c|c|c|c|}
\hline Treatment Means & Mature (M) & Clearcut (CC) & High Flow (HF) & Debris Flow (DF) & $\mathrm{p}$ \\
\hline Site Abundance (max) & $648(915)$ & $893(1123)$ & $2151(5044)$ & $3167(6697)$ & 0.22 \\
\hline$\%$ Top 10 of Abundance & 62 & 63 & 76 & 74 & 0.23 \\
\hline$\%$ Top 3 of Abundance & 37 & 39 & 50 & 62 & 0.01 \\
\hline$\%$ Abundance Chironomid taxa ${ }^{1}$ & 28 & 21 & 41 & 30 & 0.06 \\
\hline$\%$ Abundance Baetis spp. ${ }^{1}$ & 5 & 13 & 10 & 22 & 0.24 \\
\hline
\end{tabular}

1: percentages in top ten most abundant taxa in sample

Scaling the disturbance response to percent contribution of abundance avoided the effect of richness alone. Abundance treatment means ranged from 648 to 3167 individuals (Table 3 ). Although not significant, the means were surprisingly suggestive of larger numerical sample sizes in the high flow and debris flow sites. Taxa richness within individual sites was not strongly influenced by number of individuals collected (Pearson's $r=0.27$ ). Differences in abundances among treatments appear to be inflated by a few highly abundant taxa (i.e., Simulium spp., Baetis tricaudatus, Micropsectra spp., with dominance of Tvetenia bavarica gr. only at the high flow sites). This was seen in the differences with percentages in abundance of top three taxa at high flow and debris flow treatments.

The analysis of assemblages at full taxonomic resolution clustered along regional groups outweigh any disturbance signal. However, when analyzed at a broader taxonomic scale (major orders and Diptera family Chironomidae) treatment-based differences were observed in the hierarchical agglomerative clustering (Figure 2). Except for two sites, M2 and HF4, the assemblages clustered into two larger groups. The uppermost cluster of five sites from the Coast Range sites was distinct from the second cluster of nine sites. Within that second cluster there was a distinct split between three DF sites and the other six sites (Figure 2). The next separation was geographically based on three $\mathrm{M}$ and two CC sites from the Coast Range (two of the CC sites subsequently paired with the HF samples). Three of the DF samples were subsequently grouped together in the non-Coast Range branch. The most dissimilar site (M2) had low Chironomidae richness, while HF4 had the most Trichopterans and the fewest Plecopterans.

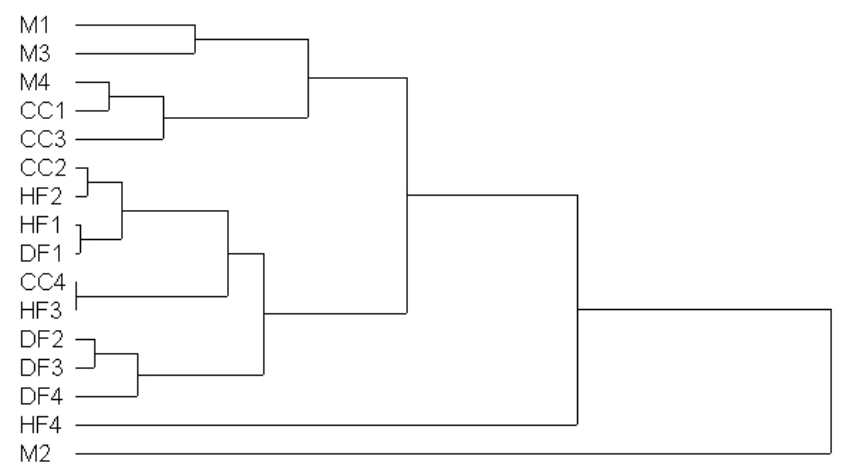

Figure 2. Hierarchical Agglomerative Clustering of Sites within Four Disturbance Treatments

\section{Discussion}

We did not expect our localized study site richness to approach the richness levels in the multi-year efforts at Berry Creek and Lookout Creek. Those intensive studies estimated the upper limit of how many species can inhabit a site in the Coast Range and Western Cascade ecoregions. Total richness for all the sites in the three projects examined herein was about half of the HJ Andrews (449 taxa) and Berry Creek $(\approx 300$ taxa $)$ totals. These data suggest that the individual site sampling intensity we used failed to encounter about 200 resident species. Our sampling targeted riffle habitat and occurred only once during the late spring, versus the more intensive studies which included multiple gear types (emergent and drift sampling) and multiple seasons that allowed a more comprehensive sampling. For example, both Progar and Moldenke [20] and Banks et al. [21] found more Chironomid taxa in spring. In one Oregon Cascades study $40 \%$ of emergent species were captured at only one of five streams (each with five replications) [22]. In the Oregon Coast Range study, 196 taxa were collected but 43 were found at only one of 18 sites within $40 \mathrm{~km}^{2}$ study area [18]. Interestingly, eight years after disturbance related to the Mt. St. Helens volcanic eruption richness was high (200 species) but most taxa were uncommon [23]. Rare taxa may be the main biological basis of disturbance responses. After a physical change, taxa that were rare in pre-disturbance conditions may find post-disturbance conditions better suited for their habitat requirements.

Disturbance research typically focuses on a single disturbance, given the random nature of disturbances such as debris flows. We needed to capitalize on existing datasets with similar sampling methods for our analysis. Our study showed that different disturbance types and severity elicited differences in assemblage response. Overall total richness differed across disturbance types, although the assemblage differences were most evident in two taxonomic categories: Ephemeroptera and Chironomidae. However, the responses suggested that different fundamental process caused separate responses. One important difference among these disturbance types is the extent of change. Clearcuts lost canopy, debris flows lost channel roughness and canopy, and high flow disturbances had at least a rearrangement of the substrate. In both clearcuts and debris flows the loss of canopy results in immediate increases in insolation and therefore probably increases stream temperature $[15,24]$ and 
overall instream production [25]. The change in insolation benefits any taxa better suited to warmer conditions and influences metabolism, including the rate of maturation of instream biota. Increases in degree days might have had a stronger impact on multi-voltine taxa such as many Chironomid species [26,27]. In contrast, higher Ephemeroptera richness after debris flow and high flow disturbances may be due to dispersal to newly formed habitats and subsequent population growth [28]. Post-disturbance studies of debris flows in Washington and Oregon also reported a strong response of Chironomidae and the Ephemeropteran genus, Baetis [29,30]. Drifting Ephemeropterans were early and successful colonizers in newly formed physical habitat after a debris flow [29]. Because flighted dispersal limits recolonization by particularly weak flyers like these two groups [31], rapid colonization would be more likely to result from upstream drift.

Both faunal richness shifts and possibly higher total densities following all three types of severe disturbances are rather surprising in their amplitude. We hypothesize that the increases in richness after disturbance are probably not from taxa that colonized from a distant watershed, but from species that colonized from less-impacted locations upstream. We cannot prove that the respondents were local because presumably they were in unusual and unsampled microhabitats that only an intensive pre-disturbance sampling could have revealed. Community structure post-disturbance is characterized by both dominance of only a very few species (with $56 \%$ of the total abundance comprised of the top three species compared to only $38 \%$ in mature and clearcut areas) and higher community richness. Each of the disturbances changed assemblage characteristics that, while probably transitory, suggest these disturbances elicit landscape-scale variability in biological diversity, perhaps not through recruitment of new taxa to the altered habitat, but rather through creating habitat conditions for opportunistic local species.

From a recovery perspective, the high flow sites retained their canopies, so their ultimate storm recovery trajectory should be both fundamentally different and shorter than the debris flow sites, where channels and much of the pre-existing riparian system were excavated and deposited downstream [32]. In addition, the disturbances have created a current and future deficit of large wood [33]. Because the riparian forest is strongly linked to instream biology [34,35], the current lack and subsequent development of a riparian forest will probably dictate the available habitats in the riparian system. Comparing debris flow disturbance to clearcutting, the altered physical conditions and displaced organisms caused by debris flows exerted more impact on macroinvertebrates in headwater systems [36]. The clearcut disturbance of canopy removal causes change to instream water quality, particularly water temperature [24,37], but little of the physical instream impacts of high flows and debris flows. Because clearcut disturbance impacts were variable, they may be more remediable through management practices than the disturbance of high flows and debris flows. Near-term similarities between high flow and debris flow disturbances should change as the riparian forest rebounds in the high flow disturbance versus the initiation of revegetation along the debris flow disturbance [38].

\section{Acknowledgements}

We are especially thankful for the unique and thorough species lists compiled by Dr. Norman Anderson at Berry Creek and the stream team at the HJ Andrews Exp. Forest. Excellent taxonomic support was provided by EcoAnalysts Inc. (Moscow, ID) on the disturbance study projects.

\section{REFERENCES}

[1] J. L. Meyer, D. L. Strayer, J. B. Wallace, S. L. Eggert, G. S. Helfman, N. E. Leonard. The contribution of headwater streams to biodiversity in river networks. Journal of the American Water Resources Association, Vol. 43, No. 1, 86-103, 2007.

[2] R. J. Danehy, S. L. Johnson. Applying four principles of headwater system aquatic biology to forest management. Density Management in the $21^{\text {st }}$ Century: West Side Story, USDA Forest Service, Portland OR, 189-202, 2013.

[3] J. D. Allan, A. S. Flecker. Biodiversity conservation in running waters, Bioscience, Vol. 43, No. 1, 32-43, 1993.

[4] J. Heino, R. Paavola, R. Virtanen, T. Muotka. Searching for biodiversity indicators in running waters: do bryophytes, macroinvertebrates, and fish show congruent diversity patterns? Biodiversity and Conservation, Vol. 14, No. 2, 415-428, 2005.

[5] J. S. Richardson, R. J. Danehy. Synthesis of the ecology of headwater streams and their riparian zones in temperate forests. Forest Science, Vol. 53, No. 2, 131-147, 2007.

[6] J. L. Sabo, R. Sponseller, M. Dixon, K. Gade, T. Harms, J. Heffernan, A. Jani, G. Katz, C. Soykan, J. Watts, J. Welter. Riparian zones increase regional species richness by harboring different, not more, species. Ecology, Vol. 86, No. 1, 56-62, 2005 .

[7] F. Nakamura, F. J. Swanson, S. M. Wondzell. Disturbance regimes of stream and riparian systems - a disturbance-cascade perspective. Hydrological Processes, Vol. 14, 2849-2860, 2000.

[8] J. K. Agee. Fire Ecology of Pacific Northwest Forests, Island Press, Washington DC, 1993.

[9] C. L. May, R. E. Gresswell. Spatial and temporal patterns of debris-flow deposition in the Oregon Coast Range, USA. Geomorphology, Vol. 57, No. 3, 135-149, 2004.

[10] G. G. Ice. Assessing best management practices effectiveness at the watershed scale. Applied Engineering in Agriculture, Vol. 27, No. 6, 925-931, 2011.

[11] R. E. Bilby, R. J. Danehy,. K. K. Jones. Woodless rivers in the middle of forests. Third International Conference Wood in World Rivers, 83-85, 2015. 
[12] M. R. Cover, J. A. de la Fuente, V. H. Resh. Catastrophic disturbances in headwater streams: the long-term ecological effects of debris flows and debris floods in the Klamath Mountains, northern California. Canadian Journal of Fisheries and Aquatic Sciences, Vol. 67, No. 10, 1596-1610, 2010.

[13] G. W. Brown, J. T. Krygier. Effects of clear-cutting on stream temperature. Water Resources Research, Vol. 6, No. 4, 1133-1139, 1970.

[14] J. M. Bartholow, Estimating cumulative effects of clearcutting on stream temperatures. Rivers, Vol 7, No. 4, 284-297, 2000.

[15] R. J. Danehy, R. E. Bilby, R. B. Langshaw, D. M. Evans, T. R. Turner, W. C. Floyd, S. H. Schoenholtz, S. D. Duke. Biological and water quality responses to hydrologic disturbances in third order forested streams. Ecohydrology, Vol. 5, No. 1, 90-98, 2012.

[16] N. H. Anderson, B. P. Hansen. An annotated check list of aquatic insects collected at Berry Creek, Benton County, Oregon 1960-1984. Systematic Entomology Laboratory, Department of Entomology, Occasional Publication Number 2, Oregon State University, Corvallis OR, 1987.

[17] G. L. Parson, G. Cassis, A. R. Moldenke, J. D. Lattin, N. H. Anderson, J. C. Miller, P. Hammond, T. D. Schowalter. Invertebrates of the H.J. Andrews Experimental Forest, Western Cascade Range, Oregon. V: An Annotated List of Insects and Other Arthropods. Gen. Tech. Rep. PNW-GTR-290. US Department of Agriculture Forest Service, Pacific Northwest Research Station, Portland, Oregon, 1991.

[18] R. J. Danehy, S. Chan, G. Lester, R. B. Langshaw, T. R.Turner. Periphyton and macroinvertebrate assemblage structure in headwaters bordered by mature, thinned, and clearcut Douglas-fir stands. Forest Science, Vol. 53n No. 2, 294-307, 2007.

[19] B. McCune, J. B. Grace. Analysis of Ecological Communities. MjM Software, Gleneden Beach, Oregon, USA, 2002.

[20] R. A. Progar, A. R. Moldenke. Insect production from temporary and perennially flowing headwater streams in western Oregon. Journal of Freshwater Ecology, Vol. 17, No. 3, 391-407, 2002.

[21] J. L. Banks, J. Li, A. T. Herlihy. Influence of clearcut logging, flow duration, and season on emergent aquatic insects in headwater streams of the Central Oregon Coast Range. Journal of the North American Benthological Society, Vol. 26, No. 4, 620-632, 2007

[22] A. R. Moldenke, C. Ver Linden. Effects of clearcutting and riparian buffers on the yield of adult aquatic macroinvertebrates from headwater streams. Forest Science, Vol. 53, No. 2, 308-319, 2007.

[23] N. H. Anderson. Influence of disturbance on insect communities in Pacific Northwest streams, Hydrobiologia, Vol. 248, No. 1, 79-92, 1992.

[24] S. L. Johnson, J. A. Jones. Stream temperature responses to forest harvest and debris flows in western Cascades, Oregon. Canadian Journal of Fisheries and Aquatic Sciences, Vol. 57, No. S2, 30-39, 2000.

[25] N. J. Hetrick, M. A. Brusven, W. R. Meehan, T. C. Bjornn. Changes in solar input, water temperature, periphyton accumulation and allochthonous input and storage after canopy removal along two small salmon stream in southeast Alaska. Transactions of the American Fisheries Society, Vol. 127, 859-875, 1998.

[26] J. E. Brittain. Life history strategies in ephemeroptera and plecoptera. Mayflies and Stoneflies: Life Histories and Biology, Springer, Netherlands, 1-12, 1990.

[27] J. S. Richardson. Life cycle phenology of common detritivores from a temperate rainforest stream. Hydrobiologia, Vol. 455, No. 1-3, 87-95, 2001.

[28] R. J. Mackay. Colonization by lotic macroinvertebrates: a review of processes and patterns. Canadian Journal of Fisheries and Aquatic Sciences, Vol. 49, No. 3, 617-628, 1992.

[29] G. A. Lamberti, S. V. Gregory, L. R. Ashkenas, R. C. Wildman, K. M. S. Moore. Stream ecosystem recovery following a catastrophic debris flow. Canadian Journal of Fisheries and Aquatic Sciences, Vol. 48, No. 2, 196-208, 1991.

[30] P. M. Kiffney, C. J. Volk, T. J. Beechie, G. L. Murray, G. R. Press, R. L. Edmonds. High-severity disturbance event alters community and ecosystem properties in West Twin Creek, Olympic National Park, Washington. American Midland Naturalist, Vol. 152, No. 2, 286-303, 2004.

[31] N. Galic, G. M. Hengeveld, P. J. Van den Brink, A. Schmolke, P. Thorbek, P. E. Bruns, H. M. Baveco. Persistence of aquatic insects across managed landscapes: effects of landscape permeability on re-colonization and population recovery. PLoS ONE, Vol. 8, No. 1, e54584, 2013.

[32] P. E. Bigelow, L. E. Benda, D. J. Miller, K. M. Burnett. On debris flows, river networks and the spatial structure of channel morphology. Forest Science, Vol. 53, No. 2, 220-238, 2007.

[33] J. Welty, B. Beechie, K. Sullivan, D. Hyink, R. Bilby, C. Andrus, G. Pess. Riparian aquatic interaction simulator (RAIS): a model of riparian forest dynamics for the generation of large woody debris and shade. Forest Ecology and Management, Vol. 162, No. 2, 299-318, 2002.

[34] S. Nakano, M. Murakami. Reciprocal subsidies: dynamic interdependence between terrestrial and aquatic food webs. Proceedings of the National Academy of Sciences, Vol. 98, No. 1, 166-170, 2001

[35] C. V. Baxter, K. D. Fausch, W. C. Saunders. Tangled webs: reciprocal flows of invertebrate prey link streams and riparian zones. Freshwater Biology, Vol. 50, No. 2, 201-220, 2005.

[36] S. Kobayashi, T. Gomi, R. C. Sidle, Y. Takemon. Disturbances structuring macroinvertebrate communities in steep headwater streams: relative importance of forest clearcutting and debris flow occurrence. Canadian. Journal. Fisheries and Aquatic. Science, Vol. 67, No. 2, 427-444, 2010.

[37] R. D. Moore, J. S. Richardson. Natural disturbance and forest management in riparian zones: comparison of effects at reach, catchment, and landscape scales. Freshwater Science, Vol. 31, No. 1, 239-247, 2012.

[38] L. D'Souza, M. Reiter, L. J. Six, R. E. Bilby. Response of vegetation, shade and stream temperature to debris torrents in two western Oregon watersheds. Forest Ecology and Management, Vol. 261, No. 11, 2157-2167, 2011. 